INDO GLOBAL JOURNAL OF

PHARMACEUTICAL SCIENCES

ISSN 2249- 1023

\title{
A Preliminary Distribution Analysis of Rhododendron in North Sikkim
}

\author{
Akshay Mamgain ${ }^{1}$, Eapsa Berry ${ }^{1}$, P.L. Uniyal ${ }^{1}$, L. K. Rai ${ }^{2}$, Moaakum ${ }^{3}$, R. Geeta ${ }^{1}$ \\ ${ }^{I}$ Department of Botany, University of Delhi, Delhi-110007, India
}

${ }^{2}$ G.B. Pant Institute of Himalayan Environment and Development, Sikkim Unit, Pangthang, Post Office Penlong (East), East Sikkim-737

101, India

${ }^{3}$ Department of Botany, Kohima Science College (Autonomous), Jotsoma-797002, Nagaland, India

Address for Correspondance: Akshay Mamgain, akshay_paatra@yahoo.com ; Eapsa Berry, eapsa321@gmail.com ; P.L. Uniyal, uniyalpl@rediffmail.com ; L.K.Rai, lalitkumar_rai@rediffmail.com ; Moaakum, moakumjamir@gmail.com ; R. Geeta, rgeeta53@gmail.com

Keywords

Rhododendron;

Sikkim; Species

Distribution;

Conservation.

\begin{abstract}
Sikkim Himalaya is rich in Rhododendron diversity as it harbors 20 species. The Rhododendrons are known worldwide for their flowers for ornamental purpose. But the changing climate as well as anthropogenic disturbances is causing the species to restrict themselves to particular areas or habitats. The factors responsible for decline in the inhabited areas of rhododendrons are: global warming, landslide and soil erosion and biotic factors are construction of roads, expansion of human settlement, clearing of forest for agriculture, over-grazing and economic use of species. In the state of Sikkim we have surveyed some areas and assessed the different species for their spread. In the Pangthang (East Sikkim) area we found only one species of Rhododendron i.e. $R$. dalhousiae ssp. tashii, which is endemic to that area. In the Yumthang (North Sikkim) 10 species were assessed out of which some species were restricted to some places e.g. $R$. fulgens, $R$. hodgsoni, $R$. niveum, $R$. campylocarpum, $R$. falconeri and $R$. virgatum, and from this only one specimen each of $R$. virgatum and $R$. falconeri were found. In Lachen (North Sikkim) area seven species were collected of which $R$. falconeri, $R$. griffithianum and $R$. pumilum had restricted distribution and there was only one plant each of $R$. falconeri and R. pumilum. All the above species have been place under RET categories (Rare, Endangered and Threatened). From this it can be concluded that some species need a particular attention towards their conservation and thus they can be saved for proper functioning of ecosystem. (C) 2016 iGlobal Research and Publishing Foundation. All rights reserved.
\end{abstract}

Conference Proceedings: International Conference on Advances in Plant and Microbial Biotechnology (PMB-2017); JIIT, Noida: February 02-04, 2017

Indo Global Journal of Pharmaceutical Sciences( ISSN 22491023 ; CODEN- IGJPAI; NLM ID: 101610675) indexed and abstracted in EMBASE(Elsevier), SCIRUS(Elsevier),CABI, CAB Abstracts, Chemical Abstract Services(CAS), American Chemical Society(ACS), Index Copernicus, EBSCO, DOAJ, Google Scholar and many more. For further details, visit http://iglobaljournal.com 